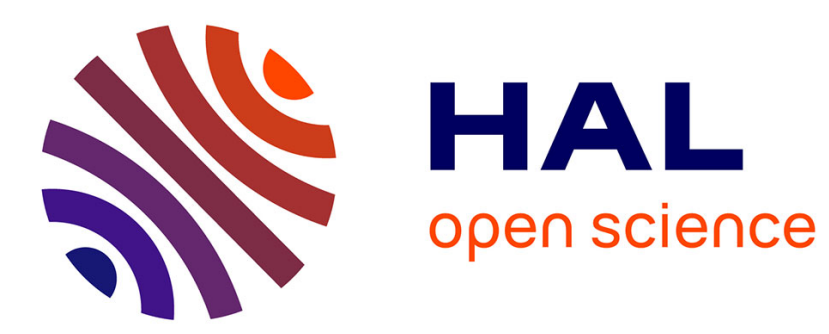

\title{
Structure of the 17-electron Cp*MoCl2(dppe): an unexpected trans geometry in the solid state
} James Fettinger, D Webster Keogh, Brett Pleune, Rinaldo Poli

\section{To cite this version:}

James Fettinger, D Webster Keogh, Brett Pleune, Rinaldo Poli. Structure of the 17-electron $\mathrm{Cp} * \mathrm{MoCl} 2$ (dppe): an unexpected trans geometry in the solid state. Inorganica Chimica Acta, 1997, 261 (1), pp.1-5. 10.1016/S0020-1693(96)05569-7 . hal-03313718

\section{HAL Id: hal-03313718 https://hal.science/hal-03313718}

Submitted on 8 Oct 2021

HAL is a multi-disciplinary open access archive for the deposit and dissemination of scientific research documents, whether they are published or not. The documents may come from teaching and research institutions in France or abroad, or from public or private research centers.
L'archive ouverte pluridisciplinaire $\mathbf{H A L}$, est destinée au dépôt et à la diffusion de documents scientifiques de niveau recherche, publiés ou non, émanant des établissements d'enseignement et de recherche français ou étrangers, des laboratoires publics ou privés. 


\title{
Structure of the 17-electron $\mathrm{Cp}^{*} \mathrm{MoCl}_{2}$ (dppe): an unexpected trans geometry in the solid state
}

\author{
James C. Fettinger, D. Webster Keogh, Brett Pleune, Rinaldo Poli * \\ Department of Chemistry and Biochemistry, University of Maryland, College Park, MD 20742, USA
}

Received 11 July 1996; accepted 26 November 1996

\begin{abstract}
Compound $\mathrm{Cp}^{*} \mathrm{MoCl}_{2}$ (dppe) crystallizes in the monoclinic space group $P 2_{1} / c, a=16.9063(10), b=11.0118(8), c=18.6128(14) \AA$, $\beta=111.713(6)^{\circ}, V=3219.3(4) \AA^{3}, Z=4, D_{\text {calc }}=1.445 \mathrm{Mg} \mathrm{m}^{-3}, \mu(\mathrm{MoK} \alpha)=0.698 \mathrm{~mm}^{-1}, R 1=0.0448, w R 2=0.0906$ for all data, $R 1=0.0337, w R 2=0.0839$ for 4754 data with $l>2 \sigma(I)$. The geometry of the compound is a four-legged piano stool as typically found for this class of compounds, but the dppe ligand occupies relative trans position whereas the previously reported $\mathrm{CpMoBr}_{2}$ (dppe) has the more common cis geometry. EPR spectroscopic investigations indicate that a mixture of isomers is present in solution and that the relative amounts of the isomers are both solvent and temperature dependent.
\end{abstract}

Keywords: Crystal structures; Molybdenum; Pentamethylcyclopentadienyl complexes; Seventeen-electron complexes

\section{Introduction}

Half-sandwich compounds with four additional ligands typically adopt the four-legged piano stool geometry. Since the ligand set provides 14 electrons for metal-ligand bonding, compounds with this stoichiometry are limited to metals with $d^{0}-d^{4}$ configurations, for a total electron count of 14-18. A large variety of solid state structures have been determined by diffraction techniques, especially for 18-electron compounds. When a bidentate ligand is present, the cis arrangement (I) is typically observed, as exemplified by the structures of $\mathrm{CpV}(\mathrm{CO})_{2}$ (dppe) [1], and $\mathrm{CpMoCl}(\mathrm{CO})$ (dppe) [2] '. However, a number of 18 -electron compounds have been shown to adopt the alternative trans geometry (II) either in the solid state by $\mathrm{X}$-ray crystallography, e.g. $\mathrm{CpMoCl}(\mathrm{CO})\left[\left(\mathrm{C}_{6} \mathrm{~F}_{5}\right)_{2} \mathrm{PCH}_{2} \mathrm{CH}_{2} \mathrm{P}\left(\mathrm{C}_{6} \mathrm{~F}_{5}\right)_{2}\right]$ [3], and $\left(\eta^{6}\right.$ toluene) $W(\mathrm{H})(\mathrm{F})$ (dmpe) [4] or in solution by NMR, e.g. $\left[\left(\eta^{6} \text {-arene }\right) \mathrm{Mo}(\mathrm{H})\left(\mathrm{PMe}_{3}\right) \text { (dmpe) }\right]^{+}[5,6]$, and [CpRu$(\mathrm{H})_{2}($ dmpe $\left.)\right]^{+}[7]$.

\footnotetext{
* Corresponding author. Present address: Laboratoire de Synthese e d'Electrosynthèse Organométallique, Facultó des Sciences 'Gabriel', 6 , Boulevard Gabriel, 21100 Dijon, France. Tel.: $+33-03,80.39 .68 .81$. Fax: +33-03.80.39.60.98. E-mail: Rinaldo.Poll@u-bourgogne.fr

'For a more extensive series of examples, see footnote 3 in Ref. [3].
}

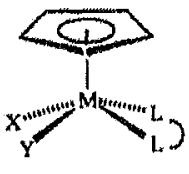

I

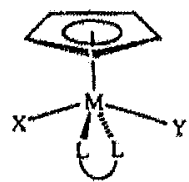

II
To the best of our knowledge, there are only two structurally characterized compounds containing a bidentate ligand and a different electron count, namely the 17-electron $\mathrm{CpMoBr}_{2}$ (dppe) [8] and [Cp*MoCl(CO) (dppe) $]^{+}[9]$, both adopting a cis structure. In addition, a cis geometry is proven in solution by EPR spectroscopy for compounds [ (ring) $\mathrm{MoCl}(\mathrm{CO})(\mathrm{dppe})]^{+}$(ring $=\mathrm{Cp}$ or $\mathrm{Cp}^{*}$ ) [9]. Here we show that the related $\mathrm{Cp}^{*} \mathrm{MoCl}_{2}$ (dppe) compound adopts the alternative trans structure in the solid state, although EPR spectroscopic investigations are consistent with more than one isomer in solution.

\section{Experimental}

The title compound can be prepared as previously reported [9]. The EPR measurements were carried out in THF and in $\mathrm{CH}_{2} \mathrm{Cl}_{2}$ solution in $3 \mathrm{~mm}$ o.d. Pyrex tubes with a Bruker ER200 spectrometer upgraded to ESP300 and equipped with a variable temperature cavity and temperature controller. Sin- 
gle crystals suitable for the $\mathrm{X}$-ray analysis were grown from $\mathrm{CH}_{2} \mathrm{Cl}_{2}$-heptane.

\subsection{X-ray analysis for $\mathrm{Cp}^{*} \mathrm{MoCl}_{2}$ (dppe)}

A clear, orange plate with dimensions $0.50 \times 0.375 \times$ $0.125 \mathrm{~mm}$ was placed and optically centered on the EnrafNonius CAD4 diffractometer. The crystal final cell parameters and crystal orientation matrix were determined from 25 reflections in the range $17.6<\theta<18.0^{\circ}$; these constants were confirmed with axial photographs. Data were collected [Mo K $\alpha$ ] with $\omega / 2 \theta$ scans over the range $2.4<\theta<25.0^{\circ}$ with a scan width of $(0.80+0.60 \tan \theta)^{\circ}$ and variable scan speed of 2.3-5.5 $\mathrm{min}^{-1}$ with each scan recorded in 96 steps with the outermost 16 steps on each end of the scan being used for background determination. Monitoring of six standard reflections well dispersed in reciprocal space at $1 \mathrm{~h}$ intervals of X-ray exposure revealed minor variations in intensity. An absorption correction was applied based upon seven $\psi$ scans with transmission factors ranging from $0.7663-0.8476$. Data were collected with the indices $\pm h k-l$ resulting in the measurement of 5826 reflections, of which 5633 unique $[R$ (int $)=0.0197]$. Data were corrected for Lorentz and polarization factors and reduced to $F_{\mathrm{o}}{ }^{2}$ and $\sigma\left(F_{\mathrm{o}}{ }^{2}\right)$. Intensity statistics and systematic absences clearly determined the centrosymmetric monoclinic space group $P 2_{1} / c$ (No. 14). The structure was determined by direct methods with the successful location of all non-hydrogen atoms except for three carbon atoms. The structure was refined by full-matrix leastsquares cycles. A subsequent difference-Fourier map revealed the location of the remaining non-hydrogen atoms within the molecule as well as several hydrogen atoms. All of the hydrogen atoms were placed in calculated positions and used for the structure factor calculations but not refined. After several cycles of refinement, all of the non-hydrogen atoms were refined anisotropically. Hydrogen atoms were allowed to refine freely during the final stages of refinement $(x y z U)$. A final difference-Fourier map was featureless with $|\Delta \rho| \leq 0.51 \mathrm{e}^{-3}$. The function minimized during the full-matrix least-squares refinement was $\sum w\left(F_{\mathrm{o}}{ }^{2}-F_{\mathrm{c}}{ }^{2}\right)$ where $w=1 /\left[\sigma^{2}\left(F_{\mathrm{o}}{ }^{2}\right)+(0.0471 \mathrm{P})^{2}+3.0486 P\right]$ and $P=$ $\left(\max .\left(F_{\mathrm{o}}^{2}, 0\right)+2 F_{\mathrm{c}}{ }^{2}\right) / 3$. An empirical correction for extinction was found to be negative and not applied. Crystal data and final agreement figures are collected in Table 1, fractional atomic coordinates are listed in Table 2, and selected bond distances and angles are in Table 3.

\section{Results and discussion}

\subsection{X-ray analysis}

As shown in Fig. 1, $\mathrm{Cp}^{*} \mathrm{MoCl}_{2}$ (dppe) adopts a trans chelate coordination mode in the solid state. Although no symmetry is crystallographically imposed, the $\mathrm{Cp}^{*} \mathrm{MoCl}_{2} \mathrm{P}_{2}$ coordination sphere has ideal $\mathrm{C}_{\mathrm{s}}$ symmetry with the mirror
Table 1

Crystal data for compound $\mathrm{Cp} * \mathrm{MoCl}_{2}$ (dppe)

\begin{tabular}{ll}
\hline Formula & $\mathrm{C}_{36} \mathrm{H}_{39} \mathrm{Cl}_{2} \mathrm{MoP}_{2}$ \\
Formula weight & 700.45 \\
Space group & $P_{2} 1 / c$ \\
$a(\AA)$ & $16.9063(10)$ \\
$b(\AA)$ & $11.0118(8)$ \\
$c(\AA)$ & $18.6128(14)$ \\
$\beta\left({ }^{\circ}\right)$ & $111.713(6)$ \\
$V\left(\AA^{3}\right)$ & $3219.3(4)$ \\
$Z$ & 4 \\
$D_{\text {calc }}\left(\mathrm{Mg} \mathrm{m}^{3}\right)$ & 1.445 \\
$\mu(\mathrm{Mo} \mathrm{K} \alpha)\left(\mathrm{mm}^{-1}\right)$ & 0.698 \\
Radiation $($ monochromated in & $\mathrm{Mo} \mathrm{K} \alpha(\lambda=0.71073 \AA)$ \\
$\quad$ incident beam) & $153(2)$ \\
Temperature $\left({ }^{\circ} \mathrm{C}\right)$ & $0.8476,0.7663$ \\
Transmission factors: max., min. & $R 1=0.0337, w R 2=0.0839$ \\
Final $R$ indices $[I>2 \sigma(I)]^{\text {a }}$ & {$[4754$ data] } \\
$R$ indices (all data) ${ }^{\text {a }}$ & $R 1=0.0448, w R 2=0.0906$ \\
\hline
\end{tabular}

${ }^{\mathrm{a}} R 1=\sum\left\|F_{\mathrm{o}}|-| F_{\mathrm{c}}\right\| / \sum\left|F_{\mathrm{o}}\right| ; w R 2=\left[\sum w\left(\left|F_{\mathrm{o}}\right|-\left|F_{\mathrm{c}}\right|\right)^{2} / \sum w\left|F_{\mathrm{o}}\right|^{2}\right]^{1 / 2}$.

plane containing the $\mathrm{Cl}$ atoms and the $\mathrm{C}(4)$ and $\mathrm{C}(9)$ atoms of the $\mathrm{Cp}^{*}$ ring. Both conformations with equivalent halogen atoms or with equivalent $\mathrm{P}$ atoms have been previously described, for instance in $\mathrm{CpMoX}_{2}\left(\mathrm{PMe}_{3}\right)_{2}(\mathrm{X}=\mathrm{Cl}$ and $\mathrm{I}$, respectively) [10], suggesting that there is no strong preference for a particular $\mathrm{Cp}^{*}$ rotamer in this system. The Mo$\mathrm{C}$ (ring) bond distances are in a narrow range with average 2.375 (15) $\AA$, the difference between the longest and shortest bond being $\Delta=0.039(3) \AA$, whereas wider ranges are observed for other similar Mo(III) compounds [11], including cis-CpMoBr ${ }_{2}$ (dppe) $(\Delta=0.15(1) \AA)$ [8]. The phenyl rings of the dppe ligands are well distanced from the $\mathrm{Cp}^{*}$ ligand, as may be appreciated from the alternative view of the molecule in Fig. 2. However, the slightly longer MoCNT distance in the title compound relative to other similar structures (see Table 4) may indicate that the dppe-Cp* van der Waals interactions are not negligible.

As shown in Table 4, the CNT-Mo-P angles are greater and the $\mathrm{CNT}-\mathrm{Mo}-\mathrm{Cl}$ angles are smaller than for any other previously reported similar structure. The dppe bite may be held responsible for the high CNT-Mo-P angle. As a result of the known rehybridization phenomenon that accompanies geometric distortions in four-legged piano stool structures [14], a larger CNT-Mo-P angle induces a smaller CNT$\mathrm{Mo}-\mathrm{Cl}$ angle. It has also been shown theoretically [14] that the more covalently $\sigma$-bonding pair of trans ligands tend to be coordinated to the metal with the smaller CNT-M-L angle and, conversely, a smaller angle favors stronger $\sigma$ interactions. This idea rationalizes the significantly shorter $\mathrm{Mo}-\mathrm{Cl}$ bond lengths in the title compound relative to the previously characterized chloride complexes (see Table 4). The Mo-P bond lengths seem to be mostly affected by steric effects, the bulkier phosphine ligands exhibiting the longest bonds (see Table 4), and the title compound exhibits distances within the range observed for the other compounds. The longer bond in comparison with the cis structure of $\mathrm{CpMoBr}_{2}$ (dppe) may 
Table 2

Atomic coordinates $\left(\times 10^{4}\right)$ and equivalent isotropic displacement parameters $\left(\AA^{2} \times 10^{3}\right)$ for $\mathrm{Cp}^{*} \mathrm{MoCl}_{2}$ (dppe)

\begin{tabular}{|c|c|c|c|c|}
\hline & $x$ & $y$ & $z$ & $U_{\mathrm{eq}}$ \\
\hline $\operatorname{Mo}(1)$ & $2933(1)$ & $186(1)$ & $2613(1)$ & $22(1)$ \\
\hline $\mathrm{Cl}(\mathrm{I})$ & $2087(1)$ & $71(1)$ & $1234(1)$ & $30(1)$ \\
\hline $\mathrm{Cl}(2)$ & $3075(1)$ & $-327(1)$ & $3922(1)$ & $34(1)$ \\
\hline$P(1)$ & $2412(1)$ & $-1962(1)$ & $2450(1)$ & $22(1)$ \\
\hline$P(2)$ & $1476(1)$ & $522(1)$ & $2620(1)$ & $22(1)$ \\
\hline$C(1)$ & $4030(2)$ & $1564(3)$ & $3343(2)$ & $37(1)$ \\
\hline $\mathrm{C}(2)$ & $4413(2)$ & $460(3)$ & $3224(2)$ & $38(1)$ \\
\hline$C(3)$ & $4246(2)$ & $325(3)$ & $2432(2)$ & $37(1)$ \\
\hline$C(4)$ & $3744(2)$ & $1351(3)$ & $2059(2)$ & $38(1)$ \\
\hline$C(5)$ & $3597(2)$ & $2096(3)$ & $2616(2)$ & $38(1)$ \\
\hline$C(6)$ & $4188(3)$ & $2126(5)$ & $4112(3)$ & $56(1)$ \\
\hline$C(7)$ & $5006(3)$ & $-314(5)$ & $3857(3)$ & $55(1)$ \\
\hline$C(8)$ & $4646(3)$ & $-579(5)$ & $2068(3)$ & $57(1)$ \\
\hline$C(9)$ & $3540(4)$ & $1682(6)$ & $1224(3)$ & $64(1)$ \\
\hline$C(10)$ & $3148(3)$ & $3304(4)$ & $2444(4)$ & $60(1)$ \\
\hline$C(11)$ & $2885(2)$ & $-2975(3)$ & $3276(2)$ & $25(1)$ \\
\hline$C(12)$ & $2477(3)$ & $-3326(3)$ & $3766(2)$ & $37(1)$ \\
\hline$C(13)$ & $2899(3)$ & $-4039(4)$ & $4412(2)$ & $44(1)$ \\
\hline$C(14)$ & $3707(3)$ & $-4424(4)$ & $4565(2)$ & $50(1)$ \\
\hline$C(15)$ & $4114(3)$ & $-4090(4)$ & $4079(2)$ & $54(1)$ \\
\hline$C(16)$ & $3709(2)$ & $-3369(4)$ & $3441(2)$ & $39(1)$ \\
\hline$C(21)$ & $2410(2)$ & $-2984(3)$ & $1669(2)$ & $26(1)$ \\
\hline$C(22)$ & $2873(2)$ & $-2725(3)$ & $1210(2)$ & $34(1)$ \\
\hline$C(23)$ & $2863(3)$ & $-3518(4)$ & $627(2)$ & $41(1)$ \\
\hline$C(24)$ & $2379(3)$ & $-4565(3)$ & $485(2)$ & $38(1)$ \\
\hline$C(25)$ & $1913(3)$ & $-4831(3)$ & $932(2)$ & $37(1)$ \\
\hline$C(26)$ & $1927(2)$ & $-4053(3)$ & $1523(2)$ & $32(1)$ \\
\hline$C(27)$ & $1260(2)$ & $-1965(3)$ & $2279(2)$ & $27(1)$ \\
\hline$C(28)$ & $1017(2)$ & $-961(3)$ & $2721(2)$ & $25(1)$ \\
\hline$C(31)$ & $1322(2)$ & $1394(3)$ & $3395(2)$ & $24(1)$ \\
\hline$C(32)$ & $636(2)$ & $1164(3)$ & $3619(2)$ & $31(1)$ \\
\hline$C(33)$ & $542(2)$ & $1801(3)$ & $4224(2)$ & $34(1)$ \\
\hline$C(34)$ & $1112(2)$ & $2679(3)$ & $4604(2)$ & $37(1)$ \\
\hline$C(35)$ & $1775(3)$ & $2938(4)$ & $4377(2)$ & $44(1)$ \\
\hline$C(36)$ & $1886(2)$ & $2292(3)$ & $3780(2)$ & $37(1)$ \\
\hline$C(41)$ & $653(2)$ & $1211(3)$ & $1775(2)$ & $25(1)$ \\
\hline$C(42)$ & $666(2)$ & $2454(3)$ & $1654(2)$ & $31(1)$ \\
\hline$C(43)$ & $60(3)$ & $2988(4)$ & $1018(2)$ & $38(1)$ \\
\hline$C(44)$ & $-564(2)$ & $2310(4)$ & $490(2)$ & $39(1)$ \\
\hline$C(45)$ & $-583(2)$ & $1085(4)$ & $591(2)$ & $44(1)$ \\
\hline$C(46)$ & $20(2)$ & $532(4)$ & $1234(2)$ & $37(1)$ \\
\hline
\end{tabular}

$U_{\text {eq }}$ is defined as one third of the trace of the orthogonalized $U_{i j}$ tensor.

Table 3

Selected bond distances $(\AA)$ and angles $\left({ }^{\circ}\right)$ for compound $\mathrm{Cp} * \mathrm{MoCl}_{2}$ (dppe)

\begin{tabular}{lclc}
\hline $\mathrm{Mo}(1)-\mathrm{Cl}(1)$ & $2.4361(8)$ & $\mathrm{Mo}(1)-\mathrm{C}(2)$ & $2.354(3)$ \\
$\mathrm{Mo}(1)-\mathrm{Cl}(2)$ & $2.4251(8)$ & $\mathrm{Mo}(1)-\mathrm{C}(3)$ & $2.370(3)$ \\
$\mathrm{Mo}(1)-\mathrm{P}(1)$ & $2.5025(8)$ & $\mathrm{Mo}(1)-\mathrm{C}(4)$ & $2.374(3)$ \\
$\mathrm{Mo}(1)-\mathrm{P}(2)$ & $2.4956(8)$ & $\mathrm{Mo}(1)-\mathrm{C}(5)$ & $2.383(3)$ \\
$\mathrm{Mo}(1)-\mathrm{C}(1)$ & $2.393(3)$ & $\mathrm{Mo}(1)-\mathrm{CNT}$ & $2.046(3)$ \\
$\mathrm{Cl}(1)-\mathrm{Mo}(1)-\mathrm{Cl}(2)$ & $147.95(3)$ & $\mathrm{Cl}(2)-\mathrm{Mo}(1)-\mathrm{P}(2)$ & $76.13(3)$ \\
$\mathrm{Cl}(1)-\mathrm{Mo}(1)-\mathrm{P}(1)$ & $77.30(3)$ & $\mathrm{Cl}(2)-\mathrm{Mo}-\mathrm{CNT}$ & $104.9(1)$ \\
$\mathrm{Cl}(1)-\mathrm{Mo}(1)-\mathrm{P}(2)$ & $79.43(3)$ & $\mathrm{P}(1)-\mathrm{Mo}(1)-\mathrm{P}(2)$ & $80.60(3)$ \\
$\mathrm{Cl}(1)-\mathrm{Mo}-\mathrm{CNT}$ & $107.2(1)$ & $\mathrm{P}(1)-\mathrm{Mo}-\mathrm{CNT}$ & $140.1(1)$ \\
$\mathrm{Cl}(2)-\mathrm{Mo}(1)-\mathrm{P}(1)$ & $78.51(3)$ & $\mathrm{P}(2)-\mathrm{Mo}-\mathrm{CNT}$ & $139.3(1)$ \\
\hline
\end{tabular}

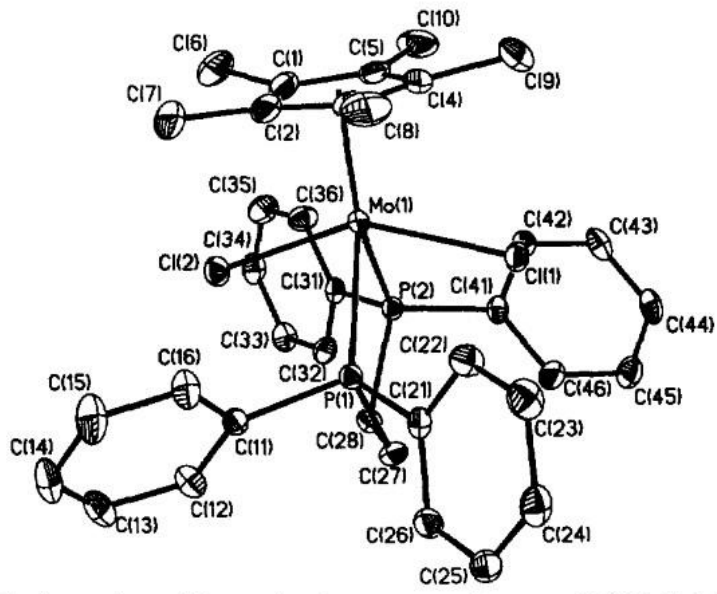

Fig. 1. A top view of the molecular geometry in trans-Cp* $\mathrm{MoCl}_{2}$ (dppe). Hydrogen atoms are not shown for clarity. Ellipsoids are drawn at the $40 \%$ probability level.

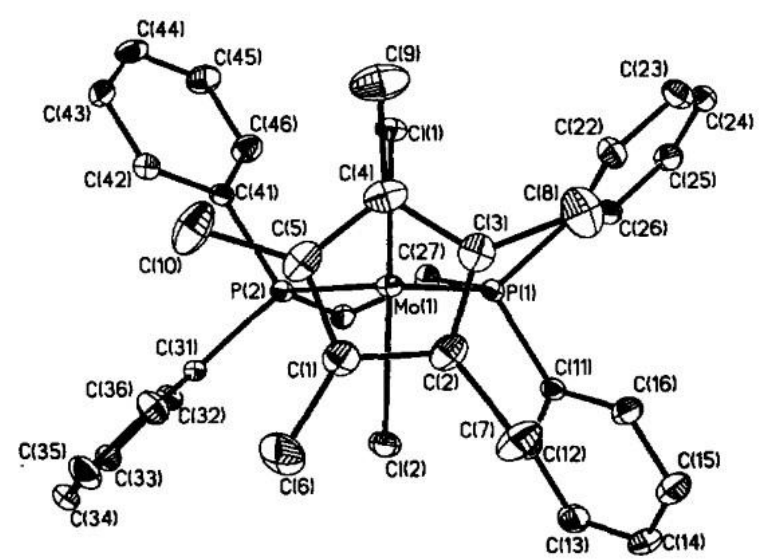

Fig. 2. A side view of the structure of trans $-\mathrm{Cp} * \mathrm{MoCl}_{2}$ (dppe). The drawing style is identical to that in Fig. 1.

be attributed to a greater strain in the 5-membered Mo(dppe) ring in the title compound, which is also indicated by the larger $\mathrm{P}-\mathrm{Mo}-\mathrm{P}$ angle $\left[80.60(3)^{\circ}\right.$ versus $75.8(1)^{\circ}$ in $\mathrm{CpMoBr}_{2}$ (dppe)] [8].

In conclusion, it appears that the observed trans structure for the title compound is determined by the reduced dppering steric interaction, in spite of the resulting greater strain in the Mo(dppe) ring.

\subsection{EPR analysis}

The EPR spectrum of compound $\mathrm{Cp}^{*} \mathrm{MoCl}_{2}$ (dppe) is complex and temperature and solvent dependent. Two major resonances are observed at room temperature in both $\mathrm{CH}_{2} \mathrm{Cl}_{2}$ and THF, one of which is a well resolved triplet and the other is a broad and unresolved feature at lower field, see Fig. 3. The $g$ values of the two resonances are essentially identical in the two solvents ( 1.964 and 2.018 in $\mathrm{CH}_{2} \mathrm{Cl}_{2}, 1.970$ and 2.015 in THF), but the relative intensity is different (the sharper triplet signal has greater relative intensity in $\mathrm{CH}_{2} \mathrm{Cl}_{2}$ ). In addition, a puzzling strong solvent dependence of the hyperfine phosphorus coupling is observed for the higher field 
Table 4

Comparison of structural parameters for $\mathrm{CpMo}$ (III) derivatives ${ }^{\text {a }}$

\begin{tabular}{|c|c|c|c|c|c|c|}
\hline Compound & $\mathrm{Mo}-\mathrm{Cl}$ & Mo-P & $\mathrm{Mo}-\mathrm{CNT}^{\mathrm{b}}$ & CNT-Mo- $\mathrm{X}^{\mathrm{c}}$ & CNT-Mo-P & Ref. \\
\hline $\mathrm{CpMoBr}_{2}$ (dppe) & & $2.46(2)$ & $1.97(1)$ & $113.8(1)$ & $111.4(7)$ & {$[8]$} \\
\hline $\mathrm{CpMoCl}_{2}\left(\mathrm{PMe}_{3}\right)_{2}$ & $2.471(3)$ & $2.482(2)$ & $1.939(8)$ & $117.4(2)$ & $113.2(1)$ & {$[10]$} \\
\hline $\mathrm{CpMoI}_{2}\left(\mathrm{PMe}_{3}\right)_{2}$ & & $2.501(2)$ & $1.951(9)$ & $117.2(1)$ & $110(3)$ & {$[10]$} \\
\hline $\mathrm{Cp} * \mathrm{MoCl}_{2}\left(\mathrm{PMe}_{3}\right)_{2}$ & $2.488(4)$ & $2.509(1)$ & d & $116.6(12)$ & $119(3)$ & {$[12]$} \\
\hline $\mathrm{Cp} * \mathrm{MoCl}_{2}(\mathrm{dppe})$ & $2.431(6)$ & $2.499(4)$ & $2.046(3)$ & $106.0(12)$ & $139.7(4)$ & this work \\
\hline $\mathrm{CpMoCl}_{2}\left(\mathrm{PMePh}_{2}\right)_{2}$ & $2.471(6)$ & $2.531(3)$ & $1.943(5)$ & $127(4)$ & $107.1(2)$ & [13] \\
\hline $\mathrm{CpMoCl}_{2}\left(\mathrm{PPh}_{3}\right)_{2}$ & $2.454(3)$ & $2.546(3)$ & $1.96(1)$ & $122.0(4)$ & $109.2(4)$ & [13] \\
\hline
\end{tabular}

a All numbers are averages of chemically equivalent structural parameters.

${ }^{b} \mathrm{CNT}=$ center of gravity of the cyclopentadienyl ring.

$\mathrm{C}=\mathrm{Cl}$ or other halogen atom.

${ }^{\mathrm{d}}$ Not reported.
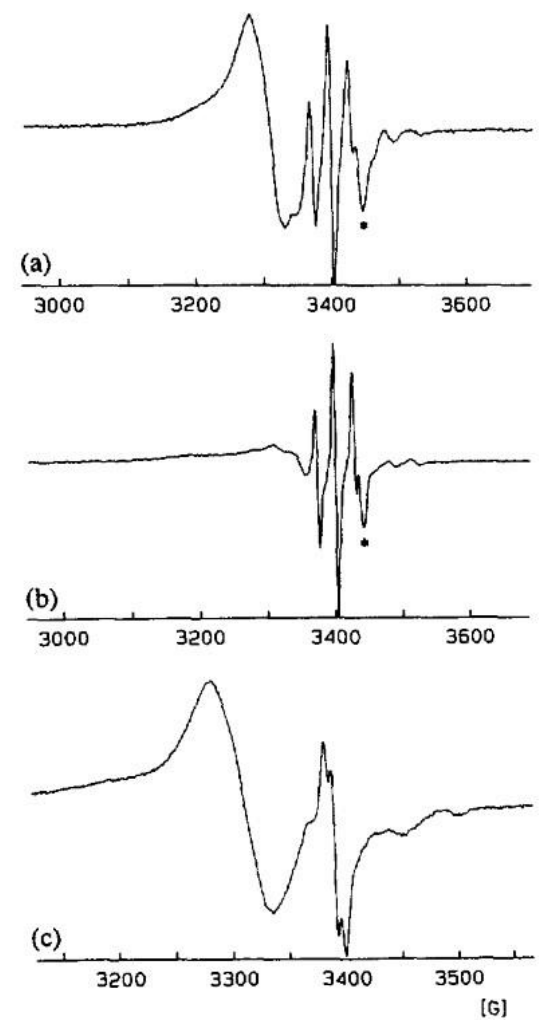

Fig. 3. EPR spectra of compound $\mathrm{Cp}^{*} \mathrm{MoCl}_{2}$ (dppe): (a) in $\mathrm{CH}_{2} \mathrm{Cl}_{2}$ at room temperature; (b) in $\mathrm{CH}_{2} \mathrm{Cl}_{2}$ at $193 \mathrm{~K}$; (c) in $\mathrm{THF}$ at room temperature. The starred resonance is due to an oxidation impurity and grows upon exposure to air.

triplet resonance $\left(a_{\mathrm{P}}=27.6 \mathrm{G}\right.$ in $\mathrm{CH}_{2} \mathrm{Cl}_{2}, 8.5 \mathrm{G}$ in THF $)$. On the other hand, the hyperfine phosphorus coupling constant is not temperature dependent. Upon cooling in either solvent, the relative intensity of the two signals changes in favor of the higher field triplet. In $\mathrm{CH}_{2} \mathrm{Cl}_{2}$, the broader feature almost disappears at $193 \mathrm{~K}$ (see Fig. 3(b)). The low-boiling $\mathrm{CH}_{2} \mathrm{Cl}_{2}$ did not permit a high temperature study. Upon warming the THF solution to $60^{\circ} \mathrm{C}$, the relative intensity changes in favor of the lower field broad signal. No broadening and coalescence of the two resonances was observed. The relative intensities in both solvents are reproducible for samples obtained from different synthetic batches and different recrystalliza-

tions, ruling out the possibility that either resonance arises from an impurity. In addition, the temperature change is fully reversible, pointing to the presence of different isomers whose interconversion is slow on the EPR time scale, but rapid during the temperature change. Previous studies have shown a similar behavior for compound $\mathrm{CpMoCl}_{2-}$ $\left(\mathrm{PMePh}_{2}\right)_{2}$, whereas other compounds [including $\mathrm{CpMoCl}_{2}-$ (dppe)] show a single averaged resonance at the X-band frequency and two resonances, a major one at $g=1.978$ 1.994 and a minor one at higher $g$, at the Q-band frequency [13].

For previously reported (ring) $\mathrm{MoCl}_{2}\left(\mathrm{PR}_{3}\right)_{2}$ systems, there is no clear correlation between the $a_{\mathrm{p}}$ (in the wide 9$26 \mathrm{G}$ range) and either the Mo-P distance or the CNT-Mo$\mathrm{P}$ angle. Possibly both structural parameters, as well as the nature of the other ligands, affect the value of $a_{\mathrm{p}}$, thus it is not possible to firmly establish whether the triplet feature or the broader resonance belongs to the structurally characterized geometry. It can be observed, however, that compounds with monodentate phosphines and a trans geometry tend to show smaller $a_{\mathrm{P}}$ values (in the 9-18 G range) than compounds with bidentate phosphines and a cis geometry [e.g. $a_{\mathrm{p}}=26 \mathrm{G}$ for $\mathrm{CpMoCl}_{2}$ (dppe), $23 \mathrm{G}$ for $\mathrm{CpMoBr}_{2}$ (dppe) ] [13]. The position of the resonance ( $g$ value), however, does not seem to depend on the cis versus trans configuration. On this basis, we tentatively suggest that the triplet feature at $g=1.987$ is due to a four-legged piano stool, the prevalent geometry being cis in $\mathrm{CH}_{2} \mathrm{Cl}_{2}$ and trans in THF. The broader feature at higher $g$, on the other hand, is tentatively assigned to another isomeric structure, possibly a pseudo-trigonal bipyramidal structure. Such an alternative structure was also suggested previously for compounds $\mathrm{CpMoCl}_{2} \mathrm{~L}_{2}$ ( $\mathrm{L}=\mathrm{PMePh}_{2}$ or $\mathrm{L}_{2}=$ dppe ) [13].

A reviewer has suggested the possibility of a reversible $\mathrm{Cl}^{-}$dissociation to afford $\left[\mathrm{Cp}{ }^{*} \mathrm{MoCl}(\text { dppe })\right]^{+} \mathrm{Cl}^{-}$. We do not believe that this process could account for the EPR observations for the following reasons. We have previously attempted to generate 15-electron species of formula $\left[\mathrm{Cp}^{*} \mathrm{MoClL}_{2}\right]^{+}$and $\mathrm{Cp}$ analogues $(\mathrm{L}=$ tertiary phosphine ligand) $[9,15]$. The $\mathrm{Cl}^{-}$abstraction from $\mathrm{Cp}^{*} \mathrm{MoCl}_{2}$ $\left(\mathrm{PMe}_{2} \mathrm{Ph}\right)_{2}$ by $\mathrm{AlCl}_{3}$ in $\mathrm{CH}_{2} \mathrm{Cl}_{2}$ generates $\left[\mathrm{Cp}^{*} \mathrm{MoCl}_{2^{-}}\right.$ 
$\left.\left(\mathrm{PMe}_{2} \mathrm{Ph}\right)_{2}\right]^{+} \mathrm{AlCl}_{4}^{-}$, suggesting that the 15-electron $\left[\mathrm{Cp} * \mathrm{MoCl}\left(\mathrm{PMe}_{2} \mathrm{Ph}\right)_{2}\right]^{+}$has sufficient reactivity to scavenge a $\mathrm{Cl}$ atom from $\mathrm{CH}_{2} \mathrm{Cl}_{2}$ [15]. However, $\mathrm{Cp}^{*} \mathrm{MoCl}_{2^{-}}$ (dppe) is perfectly stable in that solvent. On the other hand, the thermal decarbonylation from the 17 -electron $[\mathrm{CpMoCl}$ (CO) (dppe) ] ${ }^{+} \mathrm{PF}_{6}^{-}$compound in THF produces a proposed 15-electron $[\mathrm{CpMoCl}(\text { dppe })]^{+}$intermediate, which has sufficient reactivity to abstract $\mathrm{a} \mathrm{F}^{-}$ion from $\mathrm{PF}_{6}^{-}$and generate the 17-electron CpMoClF(dppe) [9]. This observation strongly suggests that a hypothetical $\left[\mathrm{Cp}^{*} \mathrm{MoCl}(\text { dppe })\right]^{+}$$\mathrm{Cl}^{-}$complex would be rather unstable relative to the 17 electron neutral dichloride complex. In addition, theoretical calculations at the MP2 and at the DFT levels on the 15electron $\mathrm{CpMoCl}_{2}\left(\mathrm{PH}_{3}\right)$ model complex indicate that this would adopt a spin quartet ground state [16,17], the EPR signal of which would not be observable at room temperature. We cannot, however, discount the possibility that [ $\mathrm{Cp}^{*} \mathrm{Mo}-$ $\mathrm{Cl}($ dppe $)]^{+} \mathrm{Cl}^{-}$is accessed as an intermediate or transition state during the hypothetical cis/trans isomerization of the title compound.

\section{Supplementary material}

Tables of crystal data, bond distances and angles, anisotropic thermal parameters, and $\mathrm{H}$-atom coordinates, and calculated and observed structure factors for compound Cp ${ }^{*} \mathrm{MoCl}_{2}$ (dppe) (23 pages) are available from author R.P. upon request. The crystallographic data have also been deposited with the Cambridge Crystallographic Data Centre.

\section{Acknowledgements}

We are grateful to the National Science Foundation (grant CHE-9508521) and the Department of Energy Office of
Energy Research (grant No. DEFG029ER14550) for support of this work. The EPR spectrometer was upgraded in part with NSF funds (CHE-9225064).

\section{References}

[1] D. Rehder, I. Müller and J. Kopf, J. Inorg. Nucl. Chem., 40 (1978) 1013-1017.

[2] M.A. Bush, A.D.U. Hardy, L. Manojlovic-Muir and G.A. Sim, J. Chem. Soc. (A), (1971) 1003-1009.

[3] M.F. Ernst and D.M. Roddick, Inorg. Chem., 29 (1990) 3627-3630.

[4] M.L.H. Green, A.K. Hughes, P. Lincoln, J.J. Martin-Polo, P. Mountford, A. Sella, L.-L. Wong, J.A. Bandy, T.W. Banks, K. Prout and D.J. Watkin, J. Chem. Soc., Dalton Trans., (1992) 2063-2069.

[5] M. Canestrari, M.L.H. Green and A. Izquierdo, J. Chem. Soc., Dalton Trans., (1984) 2795-2801.

[6] H.E. Bunting, M.L.H. Green and P.A. Newman, J. Chem. Soc., Dalton Trans., (1988) 557-577.

[7] M.S. Chinn and D.M. Heinekey, J. Am. Chem. Soc., 109 (1987) 58655867.

[8] S.T. Krueger, B.E. Owens and R. Poli, Inorg. Chem., 29 (1990) 20012006.

[9] J.C. Fettinger, D.W. Keogh and R. Poli, J. Am. Chem. Soc., 118 (1996) $3617-3625$.

[10] S.T. Krueger, R. Poli, A.L. Rheingold and D.L. Staley, Inorg. Chem., 28 (1989) 4599-4607.

[11] R. Poli, J. Coord. Chem. B, 29 (1993) 121-173.

[12] R.T. Baker, J.C. Calabrese, R.L. Harlow and I.D. Williams, Organometallics, 12 (1993) 830-841.

[13] R. Poli, B.E. Owens, S.T. Krueger and A.L. Rheingold, Polyhedron, 11 (1992) 2301-2312.

[14] Z. Lin and M.B. Hall, Organometallics, 12 (1993) 19-23.

[15] F. Abugideiri, D.W. Keogh, H.-B. Kraatz, R. Poli and W. Pearson, J. Organometal. Chem., 488 (1995) 29-38.

[16] R. Poli, Chem. Rev., 96 (1996) 2135-2204.

[17] I. Cacelli, D.W. Keogh, R. Poli and A. Rizzo, New J. Chem., 21 (1997) 133-135. 